dilatations of the veins, from the deposition and aggregation of the earthy mat. the veins, in a similothers lave imagined that they originatc in the coats of teries, and are subsequently to the calcarcous concretions in the coats of arsmooth surface, are opposed to thic lied. Their rounded form, and uniformly to the inner coat of the vein Tielater cxplanation. When they are attached from inflammation excited by thedemann suggests that the conuexion arises coagulable lymph.- London their presence, and tie consequent effusion of Zeiluchift fur Physiologie, iv. 6 . 1 heft.

7. Case of Puerperal Peritonilis, followed by Aseites and the Spontaneons
Perforation of the Abdominal Paricles. Pextoes in the Nerue Mledicale for on the screnteenth or eighteentl, diy uf the dio openings were formed, one another tuo days afterwards in the discasc, bencath the umbilicus;

\title{
MATERIA MEDICA.
}

8. New Principle in Cinchona.-M. Vax Mosa has discovered a ncw prin. eiple in the bark of the Cinelona montana, which is whitc, crystallizablc, and cured intermittent The diseorercr calls this Monlanine, and says that he has Buchner, Repertorium fur die Pharmacie.

9. Lunar Caustic Blister.

cal and Physical Suciely of Calcutla 5 $\mathrm{l}_{1}$ Vol. of the Transactions of the Mrediin which tbe lunar caustic is reconime find an articlc by J. C. Boswrel, F.sq. producing resication. Mr. H. Las is a substitute to cantharides for rbcumatism, dysentery, \&c. H.ith Jised that remedy in pncumonia, phthisis, ed by slightly wetting the part, had says, decided utility. The blistcr is forn. caustic orcr the surface to be blistercl, firstowly drawing the stick of lunar The fluid is discharged by small perce, first longitudinally, and then across. cation of the caustic; and no punctures, in about ten hours aftcr the appli. comes in two or threc dars sufficing being used throughout, the surface be. the same place if neccsary. ters in the course of trcatini a pulmonary on morc than thirty of these blis. the cure procecds.

The advantages which the nitrate of silver, applicd as a blister, possesses mediatc, and cffect accorling to $\mathbf{M I r}$. B. appcars to be that its action is morc im. quircs no dressing-is casy of appliention, s.ut affect the urinary organs-re. carried about.

Mr. Tuining, the intelligent secretary of the society, has appended to th paper some remarks confirmatory of the statements of Mr. Iloswcll. that he has found the caustic blisters very useful in of Mr. lloswcll. lle sars duration, affeeting the joints, and unattended with pyrexia, and with littlc or no
acute loeal inflammation.

10. On the Diuretic Properlies of I. M. 13th Light Dragoons, at Trich Lichen Futguris. By Dr. Steressos, of abundancc at Bangalore and 7 richinopoly.-The Lichen vulgaris is found in its decoction in milk is used by the natyo its Tamul name is Kull-paslie; anil but they are not aequainterl with its natives in that part of India as a diuretic; the loins. Dr. Stevenson recom its efficzey when applied as a poultice orer brised in a mortar; it is then to be appliche lichen to bc boiled in water, and a poulticc, and renewed twice to be applied orer the region of the kidncrs, as 


\section{Practice of Aledicine.}

dicines, wben requisite. Dr. S. mentions the case of a man, who had suffered for many montbs from dropsy, his abdomen being very tumid and undulating; dry. $\mathbf{A}$ poulticc of Lichen rulgarous; cuuntenance bloatcd, and skin barsh and its diurctic effects so frecly, that a was applicd orcr eacl kidncy, and produccd to the interruption of rest. In tenart of lirine was voided cvery second hour, had decreased a foot: tlic dropsy days the circumfercnce of the man's belly The remedy was used in Julv, 1829, cured, and thic man's licalth restorcd. liearl from, sixtcen months after. sarca, the symptoms of which wer. The 2d case was 2 Dragoon, who liad anaand the man died; when the were spcedily removed, but the disease retumed, with disease of the heart. Dr. S. loweal symptoms were found to be connected with bencfit; but the patient was nows of the lichen being uscd in a third case, at the samc timc; thereforc, the effcets of this care, and used other medicines case. The Lichen vulgaris is commonly fof the rcmedy might be doubtful in that and the lower brancbes and denuded roots of the liseckan, growing on rocks, the Mledical and Physical Society of Calculta, $F_{0}$ l. $Y$.

11. Remarks on the Medieal Properties of the Harilatie, or Mfyrobalan. Trans lated from scveral Native Micdical Works, by R.Asll KALIKIsszx, and rcad at the Mcdical Socicty's Meeting, on the $7 \mathrm{tb}$ of $\mathrm{Mlay}, 1831$. - The fruit of the Terlisl, is much uscd as a medicined Ilaritakec in Bengal, and Myrobalan in Enging and administering this medicin the natives of lndia: their modes of preparis raried according to the scason of the combination with otbcr substances, the effect intended to be produced. cd mediciually; that chicfly in use, is the small binds of the baritakce are employin Bengallee, Jungcia haritakec. Is is consll black myrobalan, wbich is called rately warm description, wbich has some tonic a mild purgatirc, of a modewith great advantagc in many clironic complaines propertics, and is often used tions, improve the gencral licaltb, and complaints. It is said to remove obstrucous disorders, and liypochondriacal affectiongthen the digestion; relieving bdilife." A regular coursc of this mcdicine is prescribed increasing the bappiness of ducing the above effects; and it is recome is prescribed for the purpose of promonths. By this sceount, haritakec secms to produe continued for several 31r. Abcrnetby's blue pill systcm, besides to produce all the good effects of out any of the cril conscquences frequen many others of great bencfit; with. tracted usc of mercurial preparations The arising from the liabitual and procxtolled, that it secms well wortlys. The efficacy of this medicine is so much becn impaircl for a long time; and ef a trial on Europeans, whose healtl has referred to weak digcstion, torpid bowecially wberc the principal disorcer is with lowness of spirits, and corpid bowels, bilious disordcr, and gcncral dcbility: grains of the black myrobalan in ed every morning. In protracted cowronic, with ten grains of black salt, repcattinued for threc montlis: during the firstiscases, the haritakec should be consalt as above stated. during the the first month, the combination with black ten grains of brown Jagry sugar, arc ordered to be taken cvery day; and for
the third month, twenty grains of laritakce, and ten grains of caraway seeds in powder.-Ibid.

\section{PRACTICE OF MEDICINE.} 12. Theatment of Gastrodynia of Dr. Grarss. - Sept. 1828. Rev. I. D- $-y$,
xt. 36 , rather corpule nt, of tempcratc habits, has suffered for threc ycars from
violent sttacks of gastrodynia. violent sttacks of gastrodynia. They last somctimes for forty-eight bours, and during their continuance the agony is described to be so great as to make even 